\title{
Synthesis, Spectroscopic Characterization and Antibacterial Activity of Organotin(IV) Complexes Containing Hydrazone Ligand: X-ray Single Crystal Structure of $\left[n-\mathrm{Bu}_{2} \mathrm{Sn}\left(\mathrm{H}_{2} \mathrm{PAI}\right) . \mathrm{H}_{2} \mathrm{O}\right]$
}

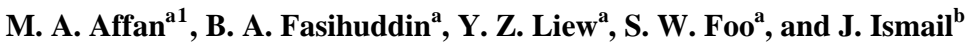 \\ ${ }^{a}$ Deptartment of Chemistry, Faculty of Resource Science and Technology, Universiti Malaysia \\ Sarawak, 94300 Kota Samarahan, Sarawak, Malaysia \\ ${ }^{b}$ Department of Plant Science, Faculty of Resource Science and Technology, Universiti Malaysia \\ Sarawak, 94300 Kota Samarahan, Sarawak, Malaysia
}

Received 2 January 2009, accepted in final revised form 17 April 2009

\begin{abstract}
Five new organotin(IV) complexes with pyruvic acid isonicotinoyl hydrazone $\left[\mathrm{H}_{4} \mathrm{PAI}(\mathbf{1})\right]$ of the general formula $\left[\mathrm{Me}_{2} \mathrm{Sn}\left(\mathrm{H}_{2} \mathrm{PAI}\right)\right](2),\left[\mathrm{R}_{2} \mathrm{Sn}\left(\mathrm{H}_{2} \mathrm{PAI}\right) \cdot \mathrm{H}_{2} \mathrm{O}\right][\mathrm{R}=n-\mathrm{Bu},(3)$ or $\mathrm{Ph}$, (4)], $\left[\mathrm{RSnCl}\left(\mathrm{H}_{2} \mathrm{PAI}\right) \cdot \mathrm{H}_{2} \mathrm{O}\right][\mathrm{R}=\mathrm{Me}(5)$ or $\mathrm{Ph}(\mathbf{6})]$ have been synthesized in the presence of base in absolute methanol in 1:2:1 mole ratio (metal:base:ligand). All organotin(IV) complexes are characterized by elemental analyses, molar conductance values, UV-Visible, IR and ${ }^{1} \mathrm{H}$ NMR spectral studies. The crystal structure of organotin(IV) complex (3) has also been determined by X-ray crystallography diffraction analyses. Complex $\left[n-\mathrm{Bu}_{2} \mathrm{Sn}\left(\mathrm{H}_{2} \mathrm{PAI}\right) \cdot \mathrm{H}_{2} \mathrm{O}\right]$ (3) is orthorhombic with space group $P 2(1) / c$ with $a=27.517(5), b=9.6574(18), c=15.742(3)$ $\AA, \alpha=90^{\circ}, \beta=90^{\circ}, \gamma=90^{\circ}, V=4183.4(13) \AA^{3}, Z=8$ and $D_{\text {calc }}=1.448 \mathrm{mg} \mathrm{m}^{-3}$. The complex $[n-$ $\left.\mathrm{Bu}_{2} \mathrm{Sn}\left(\mathrm{H}_{2} \mathrm{PAI}\right) \cdot \mathrm{H}_{2} \mathrm{O}\right]$ (3) shows a distorted octahedral geometry with coordination for the central tin(IV) atom and exhibits two monomeric structures in one unit cell. In the complex (3), the pyruvic acid isonicotinoyl hydrazone ligand is coordinated to the tin(IV) as dinegative tridentate chelating agent via the carboxylic-O, enolic-O and imine- $\mathrm{N}$ atoms. Hydrazone ligand (1) and its organotin(IV) complexes have also been screened for their antimicrobial activities and found to be relatively active.
\end{abstract}

Keywords: Organotin(IV) complexes; Hydrazone ligand; Spectral studies; Crystal structure; Antibacterial activity.

(C) 2009 JSR Publications. ISSN: 2070-0237 (Print); 2070-0245 (Online). All rights reserved.

DOI: 10.3329 /jsr.v1i2.1775

\section{Introduction}

In recent years, many organotin(IV) compounds have received attention both in academic and applied research because of the ability of tin(IV)/organotin(IV) to afford stable bonds with carbon as well as with other hetero atoms. On the other hand, organotin(IV) compounds have been tested for their in-vitro activity against a large variety of tumour cell lines and have been found to be as effective as or better than traditional heavy metal

\footnotetext{
${ }^{1}$ Corresponding author: maaffan@frst.unimas.my
} 
anticancer drugs such as cisplatin [1]. In addition to the aforesaid applications, organotin(IV) compounds are also of interest in view of the considerable structural diversity they possess. This aspect has been attracting the attention of a number of researchers and a multitude of structural types have been discovered [2, 3]. Organotin complexes have potential applications in organic synthesis, catalysis, medicinal chemistry and biotechnology [4-5]. Recently, several novel molecular structures of organotin(IV) complexes with hydrazone ligands have been reported by Affan et al. [6, 7]. To the best of our knowledge, no work has been done on the tin metal chelating and the antibacterial activity studies of pyruvic acid isonicotinoyl hydrazone ligand with diorganotin(IV) dichloride. We report here the synthesis and characterization of hydrazone ligand (1) (Scheme 1) and its organotin(IV) complexes (2-6), including the crystal and molecular structure of $\left[n-\mathrm{Bu}_{2} \mathrm{Sn}\left(\mathrm{H}_{2} \mathrm{PAI}\right) \cdot \mathrm{H}_{2} \mathrm{O}\right]$ (3). The antimicrobial activity of the hydrazone ligand (1) and its organotin(IV) compounds (2-6) are evaluated using various types of bacteria.<smiles>CC(=O)C(=O)O</smiles>

Pyruvic acid<smiles>NNC(=O)c1ccncc1</smiles>

Isonicotinic hydrazide

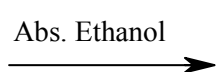<smiles>C/C(=N\NC(=O)c1ccncc1)C(=O)O</smiles><smiles>[I-][I-]</smiles>

Scheme 1

\section{Results and Discussion}

\subsection{Synthesis}

The hydrazone ligand $\left[\mathrm{H}_{4} \mathrm{PAI}(\mathbf{1})\right]$ was synthesized by the condensation reaction of isonicotinic hydrazide with pyruvic acid in 1:1 mole ratio in absolute ethanol. Five new organotin(IV) complexes (2-6) of the ligand (1) were synthesized by direct reaction of the appropriate organotin(IV) halide(s) with ligand (1) in the presence of a base under nitrogen atmosphere. The addition of base in the reaction mixture was used for the 
deprotonation of the ligand (1). The physical properties and elemental analyses of the ligand (1) and its organotin(IV) complexes (2-6) are shown in Table 1. All organotin(IV) complexes are soluble in most common solvents. The molar conductance of $10^{-4} \mathrm{M}$ solutions of the organotin(IV) complexes in DMF/DMSO solvents lie in the range 20-31 $\mathrm{ohm}^{-1} \mathrm{~cm}^{2} \mathrm{~mol}^{-1}$ (Table 2), which show their non-electrolytic nature [8].

Table 1. Physical and analytical data of ligand (1) and its organotin(IV) complexes (2-6).

\begin{tabular}{|c|c|c|c|c|c|c|}
\hline \multicolumn{2}{|l|}{ Compounds } & \multirow[t]{2}{*}{ Colour } & \multirow[t]{2}{*}{ m.p. $\left({ }^{\circ} \mathrm{C}\right)$} & \multicolumn{3}{|c|}{ Found (calc.) \% } \\
\hline & & & & $\mathrm{C}$ & $\mathrm{H}$ & $\mathrm{N}$ \\
\hline $\mathrm{H}_{4} \mathrm{PAI}$ & (1) & White & $208-210$ & $\begin{array}{c}52.16 \\
(52.17)\end{array}$ & $\begin{array}{c}4.33 \\
(4.35)\end{array}$ & $\begin{array}{c}20.30 \\
(20.29)\end{array}$ \\
\hline$\left[\mathrm{Me}_{2} \mathrm{Sn}\left(\mathrm{H}_{2} \mathrm{PAI}\right)\right]$ & (2) & $\begin{array}{l}\text { Pale- } \\
\text { yellow }\end{array}$ & $286-288$ & $\begin{array}{c}37.40 \\
(37.39)\end{array}$ & $\begin{array}{c}3.67 \\
(3.68)\end{array}$ & $\begin{array}{c}11.89 \\
(11.90)\end{array}$ \\
\hline$\left[n-\mathrm{Bu}_{2} \mathrm{Sn}\left(\mathrm{H}_{2} \mathrm{PAI}\right) \cdot \mathrm{H}_{2} \mathrm{O}\right]$ & (3) & $\begin{array}{l}\text { Pale- } \\
\text { yellow }\end{array}$ & $130-132$ & $\begin{array}{c}44.83 \\
(44.84)\end{array}$ & $\begin{array}{c}5.74 \\
(5.75)\end{array}$ & $\begin{array}{c}9.23 \\
(9.23)\end{array}$ \\
\hline$\left[\mathrm{Ph}_{2} \mathrm{Sn}\left(\mathrm{H}_{2} \mathrm{PAI}\right) \cdot \mathrm{H}_{2} \mathrm{O}\right]$ & (4) & $\begin{array}{l}\text { Pale- } \\
\text { yellow }\end{array}$ & $230-232$ & $\begin{array}{c}50.90 \\
(50.91)\end{array}$ & $\begin{array}{c}3.85 \\
(3.84)\end{array}$ & $\begin{array}{c}8.49 \\
(8.48)\end{array}$ \\
\hline$\left[\mathrm{MeSnCl}\left(\mathrm{H}_{2} \mathrm{PAI}\right) \cdot \mathrm{H}_{2} \mathrm{O}\right]$ & (5) & $\begin{array}{l}\text { Pale- } \\
\text { yellow }\end{array}$ & $244-246$ & $\begin{array}{c}30.60 \\
(30.58)\end{array}$ & $\begin{array}{c}3.05 \\
(3.06)\end{array}$ & $\begin{array}{c}10.71 \\
(10.70)\end{array}$ \\
\hline$\left[\mathrm{PhSnCl}\left(\mathrm{H}_{2} \mathrm{PAI}\right) \cdot \mathrm{H}_{2} \mathrm{O}\right]$ & (6) & $\begin{array}{l}\text { Pale- } \\
\text { yellow }\end{array}$ & $268-270$ & $\begin{array}{c}39.62 \\
(39.65)\end{array}$ & $\begin{array}{c}3.07 \\
(3.08)\end{array}$ & $\begin{array}{c}9.25 \\
(9.24)\end{array}$ \\
\hline
\end{tabular}

Table 2. Molar conductance of organotin(IV) complexes (2-6) of ligand (1).

\begin{tabular}{ccc}
\hline Compounds & & $\begin{array}{c}\text { Molar conductance, } \Lambda_{m} \\
\left(\mathrm{ohm}^{-1} \mathrm{~cm}^{2} \mathrm{~mol}^{-1}\right)\end{array}$ \\
\hline$\left[\mathrm{Me}_{2} \mathrm{Sn}\left(\mathrm{H}_{2} \mathrm{PAI}\right)\right]$ & $(\mathbf{2})$ & 20 \\
{$\left[n-\mathrm{Bu}_{2} \mathrm{Sn}\left(\mathrm{H}_{2} \mathrm{PAI}\right) \cdot \mathrm{H}_{2} \mathrm{O}\right]$} & $(\mathbf{3})$ & 31 \\
{$\left[\mathrm{Ph}_{2} \mathrm{Sn}\left(\mathrm{H}_{2} \mathrm{PAI}\right) \cdot \mathrm{H}_{2} \mathrm{O}\right]$} & $(\mathbf{4})$ & 27 \\
{$\left[\mathrm{MeSnCl}\left(\mathrm{H}_{2} \mathrm{PAI}\right) \cdot \mathrm{H}_{2} \mathrm{O}\right]$} & $(\mathbf{5})$ & 22 \\
{$\left[\mathrm{PhSnCl}\left(\mathrm{H}_{2} \mathrm{PAI}\right) \cdot \mathrm{H}_{2} \mathrm{O}\right]$} & $(\mathbf{6})$ & 26 \\
\hline
\end{tabular}

\subsection{Electronic absorption spectra}

The UV-Visible electronic spectra of ligand (1) and its organotin(IV) complexes (2-6) were measured at room temperature in DMF or DMSO $\left(10^{-4} \mathrm{M}\right)$ solutions over $200-600$ $\mathrm{nm}$ range (Table 3). Pyruvic acid isonicotinoyl hydrazone ligand (1) exhibited one main band at $268 \mathrm{~nm}$, which was attributed to $>\mathrm{C}=\mathrm{O}$ - and $>\mathrm{C}=\mathrm{N}$ - chromophore groups. The longer wavelength bands in the region 322-329 $\mathrm{nm}$ in the organotin(IV) complexes (2-6) are attributed to a charge transfer transition [9]. 
Table 3. The $\lambda_{\max }(\mathrm{nm})$ peaks of ligand (1) and its organotin(IV) complexes (2-6) in DMF $\left(10^{-4} \mathrm{M}\right)$.

\begin{tabular}{ccc}
\hline Compounds & & $\lambda_{\max }(\mathrm{nm})$ \\
$\mathrm{H}_{4} \mathrm{PAI}$ & $(\mathbf{1})$ & 268 \\
{$\left[\mathrm{Me}_{2} \mathrm{Sn}\left(\mathrm{H}_{2} \mathrm{PAI}\right)\right]$} & $(\mathbf{2})$ & 326 \\
{$\left[n-\mathrm{Bu}_{2} \mathrm{Sn}\left(\mathrm{H}_{2} \mathrm{PAI}\right) \cdot \mathrm{H}_{2} \mathrm{O}\right]$} & $(\mathbf{3})$ & 326 \\
{$\left[\mathrm{Ph}_{2} \mathrm{Sn}\left(\mathrm{H}_{2} \mathrm{PAI}\right) \cdot \mathrm{H}_{2} \mathrm{O}\right]$} & $(\mathbf{4})$ & 329 \\
{$\left[\mathrm{MeSnCl}\left(\mathrm{H}_{2} \mathrm{PAI}\right) \cdot \mathrm{H}_{2} \mathrm{O}\right]$} & $(\mathbf{5})$ & 322 \\
{$\left[\mathrm{PhSnCl}\left(\mathrm{H}_{2} \mathrm{PAI}\right) \cdot \mathrm{H}_{2} \mathrm{O}\right]$} & $(\mathbf{6})$ & 325 \\
\hline
\end{tabular}

\subsection{Infrared spectra}

The most significant IR bands of ligand (1) and its organotin(IV) complexes (2-6) are shown in the experimental section. The strong bands for $v(\mathrm{NH})$ stretching vibration of the free ligand (1) at $3170 \mathrm{~cm}^{-1}$ disappeared in its complexes (2-6), due to enolization of $\mathrm{CONH}$ - group followed by the formation of the complex through deprotonation. The IR spectra of the organotin(IV) complexes (2-6) show peaks $1591-1603 \mathrm{~cm}^{-1}$ due to the newly formed $\mathrm{C}=\mathrm{N}-\mathrm{N}=\mathrm{C}$ bond indicating that the coordination of the ligand (1) takes place via enol rather than the keto form. The coordination of imidol group in all the complexes (2-6) is further evident by the appearance of new bands characteristic of $v\left(\mathrm{NCO}^{-}\right)$in the range $1501-1509 \mathrm{~cm}^{-1}$ in the complexes [10]. This is further supported by the weak bands at $537-551 \mathrm{~cm}^{-1}$ assigned to $(\mathrm{Sn}-\mathrm{O})$, which are, however, absent in the free ligand (1) [11].

In organotin carboxylates, the IR spectra can provide useful information on carboxylate binding. The $v_{\mathrm{C}=\mathrm{O}}(\mathrm{COOH})$ vibration for the free ligand (1) at $1713 \mathrm{~cm}^{-1}$ disappeared in its complexes, and that the complexes (2-6) showed $v_{a s}\left(\mathrm{COO}^{-}\right)$and $v_{s}\left(\mathrm{COO}^{-}\right)$bands in the regions $1618-1627 \mathrm{~cm}^{-1}$ and $1377-1385 \mathrm{~cm}^{-1}$, respectively. The magnitude of $\operatorname{Dm}\left[v_{a s}\left(\mathrm{COO}^{-}\right)-v_{s}\left(\mathrm{COO}^{-}\right)\right]$occurring at $233-248 \mathrm{~cm}^{-1}$ indicates that the carboxylate ligand behaved as monodentate ligand under the conditions employed [12], respectively. These conclusions are supported by the results of X-ray diffraction studies.

The positive shifting of hydrazinic stretching $v(\mathrm{~N}-\mathrm{N})$ band of free ligand (1) observed at $903 \mathrm{~cm}^{-1}$ to the higher region at $916-929 \mathrm{~cm}^{-1}$ in the complexes (2-6) supports that the azomethine nitrogen is coordinated to $\mathrm{Sn}(\mathrm{IV})$ ion [13]. Coordination of the azomethine nitrogen is also consistent with the presence of a new band at $483-498 \mathrm{~cm}^{-1}$, assigned to ( $\mathrm{Sn}-\mathrm{N})$.

\section{4. ${ }^{I} H$ NMR spectra}

The ${ }^{1} \mathrm{H}$ NMR spectral data of ligand (1) and its organotin(IV) complexes (2-6) have been recorded in DMSO- $d_{6}$. The free ligand (1) showed three signals at 11.22, 7.61 and 2.20 $\mathrm{ppm}$, which are assigned to the protons associated with - $\mathrm{COOH},-\mathrm{CONH}-$ and $\left(\mathrm{H}_{3} \mathrm{C}\right) \mathrm{C}=\mathrm{N}-$, respectively. The absence of a $\mathrm{COOH}$ proton signal at $11.22 \mathrm{ppm}$, indicated deprotonation of the carboxylic proton in the complexes (2-6) [14]. A single resonance for 
the proton in $-\mathrm{NHN}=$ group in the spectrum of ligand (1) is observed at $7.61 \mathrm{ppm}$, which is absent in the spectra of the organotin(IV) complexes (2-6). This indicates the deprotonation of $-\mathrm{NHN}=$ group and the coordination of $\mathrm{O}$-amide with tin atom in the enol form [15]. The ligand shows a multiplet pattern in the region $\delta 7.71-8.80 \mathrm{ppm}$ for the pyridine ring protons, which is observed in the region $\delta 7.90-8.91 \mathrm{ppm}$ in the organotin(IV) complexes (2-6). This shifting also supports the coordination through the enolate-O atom. The azomethine proton signal due to methyl proton appears at $2.20 \mathrm{ppm}$ in the free ligand (1). The downfield chemical shift of the $-\left(\mathrm{H}_{3} \mathrm{C}\right) \mathrm{C}=\mathrm{N}$ - group in the complexes (2-6) compared to the free ligand (1) indicates that the $\mathrm{N}$-imine atom is coordinated to tin(IV) atom.

The sharp signal attributed to methyl group attached to tin atom appeared as a singlet at 0.69 and $1.20 \mathrm{ppm}$ in the complexes (2 and 5). In the complex (3), it exhibited two resonance signals as a singlet at $0.75 \mathrm{ppm}$ corresponding to the $\mathrm{CH}_{3}$ and a multiplet in the region 1.15-1.64 ppm assigned to the $\left(-\mathrm{CH}_{2}-\right)_{3}$ chain of the $n$-Bu group attached to the tin(IV) atom. Complexes 4 and 6 showed a multiplet in the region 7.22-7.78 ppm, which was assigned to $\mathrm{Sn}-\mathrm{Ph}$ protons, respectively. The comparison of the ${ }^{1} \mathrm{H}$ NMR spectra between dimethyltin(IV) complex (2) and organotin(IV) complexes (3-6) revealed that there is coordinated water molecule (signal at 5.30-5.55 ppm in the complexes (3-6)), while no signal of coordinated water molecule in the complex (2) [16]. This is further from the X-ray diffraction study.

\subsection{Crystal structure of $\left[n-B u_{2} \mathrm{Sn}\left(\mathrm{H}_{2} \mathrm{PAI}\right) \cdot \mathrm{H}_{2} \mathrm{O}\right]$ (3)}

The molecular structure along with atom numbering scheme for $\left[n-\mathrm{Bu}_{2} \mathrm{Sn}\left(\mathrm{H}_{2} \mathrm{PAI}\right) \cdot \mathrm{H}_{2} \mathrm{O}\right]$ (3) is shown in Fig. 1. The X-ray structural investigation of $\left[n-\mathrm{Bu}_{2} \mathrm{Sn}\left(\mathrm{H}_{2} \mathrm{PAI}\right) \cdot \mathrm{H}_{2} \mathrm{O}\right]$ revealed that the pyruvic acid isonicotinoyl hydrazone ligand is $\mathrm{O}, \mathrm{N}, \mathrm{O}$ - coordinated in complex (3). The crystal data and structure refinement for compound (3) are summarized

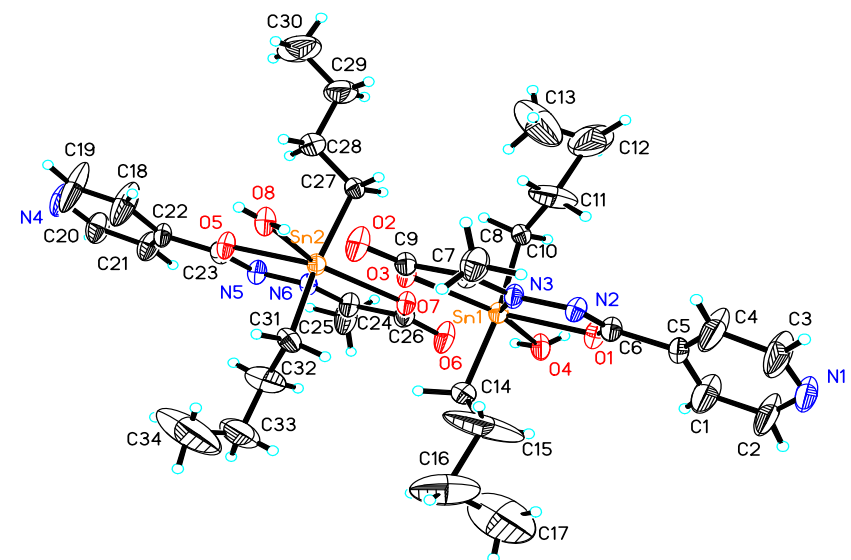

Fig. 1. Molecular structure of $\left[n-\mathrm{Bu}_{2} \mathrm{Sn}\left(\mathrm{H}_{2} \mathrm{PAI}\right) \cdot \mathrm{H}_{2} \mathrm{O}\right]$ (3). Thermal ellipsoids at the $50 \%$ level. 
in Table 4. The selected bond distances and angles for complex (3) are given in Table 5. The X-ray crystal structure of complex (3) revealed that there are two molecules in one unit cell, which is different compared to the diorganotin(IV) complexes derived from the pyruvic acid isonicotinoyl hydrazone $[11,12]$. The tin(IV) atom has six coordination geometry in a distorted octahedral arrangement in which one water molecule, one pyruvic acid isonicotinoyl hydrazone ligand and two butyl groups are coordinated to Sn(IV) center. The Sn atom lies in the ligand plane and forms a five-membered chelate ring with the ligand. The water molecule, imino nitrogen, carboxylato oxygen and enolato oxygen take the equatorial positions, while the two butyl groups take up the axial sites around the Sn atom.

The octahedral geometry in complex (3) is distorted as indicated by the bond angles of $165.4(2)^{\circ}$ and $164.7(2)^{\circ}$ for $\mathrm{C}(14)-\mathrm{Sn}(1)-\mathrm{C}(10)$ and $\mathrm{C}(27)-\mathrm{Sn}(2)-\mathrm{C}(31)$ and the deviation from $90^{\circ}$ of the angles $\mathrm{C}(10)-\mathrm{Sn}(1)-\mathrm{N}(3)$ [97.58(19) $)^{\circ}$ and $\mathrm{C}(14)-\mathrm{Sn}(1)-\mathrm{N}(3)$ [96.1(2) $]$. The coordination geometry about the $\mathrm{Sn}(\mathrm{IV})$ atom is distorted octahedral with the two butyl groups take up the axial position. The $\left.\mathrm{C}(14)-\mathrm{Sn}(1)-\mathrm{C}(10)\left[165.4(2)^{\circ}\right)\right]$ are axis deviated significantly from the linearity, probably as a consequence of the steric hindrance of the butyl groups. The sum of the angles $\mathrm{O}(1)-\mathrm{Sn}(1)-\mathrm{N}(3), \mathrm{N}(3)-\mathrm{Sn}(1)-\mathrm{O}(3), \mathrm{O}(4)-\mathrm{Sn}(1)-$ $\mathrm{O}(3)$ and $\mathrm{O}(1)-\mathrm{Sn}(1)-\mathrm{O}(4)$ is $360.03^{\circ}$, thus the atoms $\mathrm{Sn}(1), \mathrm{N}(3), \mathrm{O}(1), \mathrm{O}(3)$ and $\mathrm{O}(4)$ are almost in the same plane.

Table 4. Crystal data and the structure refinement for the complex $\left[n-\mathrm{Bu}_{2} \mathrm{Sn}\left(\mathrm{H}_{2} \mathrm{PAI}\right) \cdot \mathrm{H}_{2} \mathrm{O}\right](3)$.

\begin{tabular}{ll}
\hline Formula & $\mathrm{C}_{17} \mathrm{H}_{27} \mathrm{~N}_{3} \mathrm{O}_{4} \mathrm{Sn}$ \\
Formula weight & 456.11 \\
Crystal system & Orthorhombic \\
Space group & $P 2(1) / c$ \\
$\mathrm{Z}$ & 8 \\
$a(\AA)$ & $27.517(5)$ \\
$b(\AA)$ & $9.6574(18)$ \\
$c(\AA)$ & $15.742(3)$ \\
$\alpha\left({ }^{\circ}\right)$ & 90 \\
$\beta\left(^{\circ}\right)$ & 90 \\
$\gamma\left({ }^{\circ}\right)$ & 90 \\
$V\left(\AA^{3}\right)$ & $4183.4(13)$ \\
$D_{\text {calc }}$ (mg m $\left.{ }^{-3}\right)$ & 1.448 \\
Absorption coefficient $\left(\mathrm{mm}^{-1}\right)$ & 1.245 \\
Temperature $(\mathrm{K})$ & $298(2)$ \\
Wavelength $(\AA)$ & 0.71073 \\
Final $R$ indices $[I>2 \sigma(I)]$ & $R_{I}=0.0312, w R_{2}=0.0841$ \\
$R$ indices (all data) & $R_{1}=0.0365, w R_{2}=0.0882$ \\
Goodness-of-fit on $F^{2}$ & 0.891 \\
\hline
\end{tabular}


Table 5. Selected bond lengths and bond angles for the complex $\left[n-\mathrm{Bu}_{2} \mathrm{Sn}\left(\mathrm{H}_{2} \mathrm{PAI}\right) \cdot \mathrm{H}_{2} \mathrm{O}\right]$ (3).

\begin{tabular}{llll}
\hline Bond lengths $(\AA)$ & & & \\
\hline $\mathrm{Sn}(1)-\mathrm{C}(14)$ & $2.107(5)$ & $\mathrm{C}(6)-\mathrm{O}(1)$ & $1.279(7)$ \\
$\mathrm{Sn}(1)-\mathrm{C}(10)$ & $2.125(5)$ & $\mathrm{N}(2)-\mathrm{C}(6)$ & $1.300(7)$ \\
$\mathrm{Sn}(1)-\mathrm{O}(1)$ & $2.183(3)$ & $\mathrm{N}(2)-\mathrm{N}(3)$ & $1.403(5)$ \\
$\mathrm{Sn}(1)-\mathrm{O}(3)$ & $2.368(3)$ & $\mathrm{N}(3)-\mathrm{C}(7)$ & $1.283(6)$ \\
$\mathrm{Sn}(1)-\mathrm{O}(4)$ & $2.360(5)$ & $\mathrm{C}(9)-\mathrm{O}(3)$ & $1.290(6)$ \\
$\mathrm{Sn}(1)-\mathrm{N}(3)$ & $2.267(4)$ & $\mathrm{C}(9)-\mathrm{O}(2)$ & $1.233(6)$ \\
$\mathrm{Sn}(1)-\mathrm{N}(3)-\mathrm{N}(2)$ & $118.1(3)$ & $\mathrm{O}(3)-\mathrm{C}(9)-\mathrm{C}(7)$ & $115.8(5)$ \\
$\mathrm{Sn}(1)-\mathrm{O}(1)-\mathrm{C}(6)$ & $115.8(3)$ & $\mathrm{N}(2)-\mathrm{C}(6)-\mathrm{O}(1)$ & $128.3(5)$ \\
$\mathrm{Sn}(1)-\mathrm{O}(3)-\mathrm{C}(9)$ & $118.3(3)$ & $\mathrm{N}(3)-\mathrm{N}(2)-\mathrm{C}(6)$ & $107.9(4)$ \\
$\mathrm{Sn}(1)-\mathrm{N}(3)-\mathrm{C}(7)$ & $122.7(3)$ & $\mathrm{N}(3)-\mathrm{Sn}(1)-\mathrm{O}(3)$ & $68.08(13)$ \\
$\mathrm{O}(1)-\mathrm{Sn}(1)-\mathrm{N}(3)$ & $69.80(14)$ & $\mathrm{C}(9)-\mathrm{C}(7)-\mathrm{N}(3)$ & $115.1(5)$ \\
$\mathrm{O}(1)-\mathrm{Sn}(1)-\mathrm{O}(4)$ & $76.12(17)$ & $\mathrm{C}(14)-\mathrm{Sn}(1)-\mathrm{C}(10)$ & $165.4(2)$ \\
$\mathrm{O}(3)-\mathrm{Sn}(1)-\mathrm{O}(4)$ & $146.03(15)$ & & \\
\hline
\end{tabular}

The Sn-C bond distances of complex (3) [2.107(5) $\AA$ and 2.125(5) $\AA]$ are similar to those in $\mathrm{Me}_{2} \mathrm{Sn}\left(\mathrm{H}_{2} \mathrm{CBS}\right)$ derived from $\mathrm{Me}_{2} \mathrm{SnCl}_{2}$ [6]. In the complex (3), the $\mathrm{Sn}(1)-\mathrm{O}(1)$ bond, 2.183(3) $\AA$ is shorter than the $\mathrm{Sn}(1)-\mathrm{O}(3)$ bond, 2.368(3) $\AA$, this is a consequence of $\mathrm{O}(3)$ being a carboxylato and $\mathrm{O}(1)$ being an enolato. The Sn-N, 2.267(4) $\AA$ bond of compound (3) is longer compared to $\mathrm{Sn}-\mathrm{N}$ bond found in $\mathrm{Ph}_{2} \mathrm{Sn}\left(\mathrm{H}_{2} \mathrm{CBS}\right)$ [2.162 $\AA$ ] [7], but a little shorter than that of $\left\{\mathrm{Ph}_{2} \mathrm{Sn}\left[4-\mathrm{NC}_{5} \mathrm{H}_{4} \mathrm{CON}_{2} \mathrm{C}\left(\mathrm{CH}_{3}\right) \mathrm{CO}_{2}\right]\left(\mathrm{H}_{2} \mathrm{O}\right)\right\}_{2} \cdot \mathrm{CH}_{2} \mathrm{Cl}_{2} \cdot \mathrm{H}_{2} \mathrm{O}$ $[2.288 \AA][17]$ and is considerably less than the sum of the van der Waals radii of tin and nitrogen atom, $3.75 \AA$ [17]. The solvent molecules do not have any obvious interaction with the complex, but the water molecule, which attached to the tin(IV) is either came from the side product of the reaction or during the single crystal preparation time.

\subsection{Antibacterial activity}

The synthesized hydrazone ligand (1) and its organotin(IV) complexes (2-6) were tested for their antibacterial activity. Table 6 shows the antibacterial activity of ligand (1) and its organotin(IV) complexes (2-6). Among the synthesized complexes, the dibutyltin(IV) and diphenyltin(IV) complexes (3-4) were found to be more active than the others. The enchance activity of organotin(IV) complexes might be due to the increased lipophilic nature of these complexes arising due to the chelation [18]. In general, the organotin(IV) complexes exhibited remarkable potential in inhibiting the growth of bacteria. Therefore, these results can be used for further intensive studies of these complexes (2-6) in order to develop antibacterial compounds for the application in various fields. 
Table 6. Antibacterial activity of the ligand (1) and its organotin(IV) complexes (2-6).

\begin{tabular}{cccc}
\hline & \multicolumn{3}{c}{ Diameter of inhibition zone $(\mathrm{mm})$} \\
\cline { 2 - 4 } Compounds & E. coli & B. subtilis & S. aureus \\
\hline $\mathrm{H}_{4} \mathrm{PAI}(\mathbf{1})$ & 8 & 11 & 10 \\
{$\left[\mathrm{Me}_{2} \mathrm{Sn}\left(\mathrm{H}_{2} \mathrm{PAI}\right)\right](\mathbf{2})$} & 14 & 19 & 22 \\
{$\left[n-\mathrm{Bu}_{2} \mathrm{Sn}\left(\mathrm{H}_{2} \mathrm{PAI}\right) \cdot \mathrm{H}_{2} \mathrm{O}\right](\mathbf{3})$} & 18 & 23 & 27 \\
{$\left[\mathrm{Ph}_{2} \mathrm{Sn}\left(\mathrm{H}_{2} \mathrm{PAI}\right) . \mathrm{H}_{2} \mathrm{O}\right](\mathbf{4})$} & 15 & 20 & 24 \\
{$\left[\mathrm{MeSnCl}\left(\mathrm{H}_{2} \mathrm{PAI}\right) \cdot \mathrm{H}_{2} \mathrm{O}\right](\mathbf{5})$} & 11 & 16 & 18 \\
{$\left[\mathrm{PhSnCl}\left(\mathrm{H}_{2} \mathrm{PAI}\right) \cdot \mathrm{H}_{2} \mathrm{O}\right](\mathbf{6})$} & 14 & 18 & 20 \\
Chloramphenicol (Control) & 30 & 30 & 31 \\
\hline
\end{tabular}

\section{Experimental Methods}

\subsection{Preparation of pyruvic acid isonicotinoyl hydrazone ligand $\left(\mathrm{H}_{4} \mathrm{PAI}\right)(\mathbf{1})$}

A mixture pyruvic acid $(0.441 \mathrm{~g}, 0.005$ mole $)$ and isonicotinic hydrazide $(0.686 \mathrm{~g}, 0.005$ mole) in absolute ethanol $(50 \mathrm{~mL})$ were heated under reflux for 3-4 hours. The reaction mixture was allowed to cool to room temperature for half an hour. Then the white precipitate was filtered off and washed several times using absolute ethanol. The crystalline white solid obtained was purified by recrystallization from hot absolute ethanol and dried in vacuo over $\mathrm{P}_{2} \mathrm{O}_{5}$. Yield $=0.820 \mathrm{~g}, 72.8 \%$. m. p. $=208-210{ }^{\circ} \mathrm{C} . \lambda_{\max }(\mathrm{nm})$ (DMSO): 268. IR ( $v_{\max } \mathrm{cm}^{-1}(\mathrm{KBr}): 3178(\mathrm{NH}), 1721(\mathrm{COOH}), 1674(\mathrm{CONH}), 1619$ $(\mathrm{C}=\mathrm{N}), 1286\left(\mathrm{C}-\mathrm{O}\right.$, carboxylic), $903(\mathrm{~N}-\mathrm{N}) .{ }^{1} \mathrm{H}$ NMR $\left(\mathrm{DMSO}-d_{6}, 300 \mathrm{MHz}\right) \delta 11.22(\mathrm{br}$, $1 \mathrm{H}, \mathrm{COOH}), \delta 7.61(\mathrm{~s}, 1 \mathrm{H}, \mathrm{CONH}), \delta 2.20\left(\mathrm{~s}, 3 \mathrm{H},\left(\mathrm{H}_{3} \mathrm{C}\right) \mathrm{C}=\mathrm{N}\right), \delta 7.71,7.73(\mathrm{~d}, 2 \mathrm{H}, 3,5-$ Pyridine-H), $\delta 8.79,8.80$ (d, 2H, 2,6-Pyridine-H). Calc. for $\mathrm{C}_{9} \mathrm{H}_{9} \mathrm{~N}_{3} \mathrm{O}_{3}$ : C, 52.17; H, 4.35; N, 20.29\%. Found: C, 52.16; H, 4.33; N, 20.30\%.

\subsection{Preparation of organotin(IV) complexes}

\subsection{1. $\left[\mathrm{Me}_{2} \mathrm{Sn}\left(\mathrm{C}_{9} \mathrm{H}_{7} \mathrm{~N}_{3} \mathrm{O}_{3}\right)\right]$ (2)}

Pyruvic acid isonicotinoyl hydrazone ligand (1) (0.414g, 0.002 mole) was dissolved in hot absolute methanol $(20 \mathrm{~mL})$ under nitrogen atmosphere with potassium hydroxide $(0.236 \mathrm{~g}$, 0.0042 mole) previously dissolved in methanol $(5 \mathrm{~mL})$. The colour of the solution changed from off-white to yellow. The resulting mixture was refluxed for one hour and a solution of $\mathrm{Me}_{2} \mathrm{SnCl}_{2}(0.439 \mathrm{~g}, 0.002$ mole $)$ in methanol $(10 \mathrm{~mL})$ was added drop wise to the potassium salt of ligand solution, the color of the solution became lighter. The resulting solution was refluxed for three hours and allowed to cool to room temperature. The precipitated potassium chloride $(\mathrm{KCl})$ was removed by filtration and the filtrate was evaporated to dryness using rota evaporator to obtain the pale yellow microcrystals. The 
pale yellow micro-crystals were filtered off and washed with hexane and dried in vacuo over $\mathrm{P}_{2} \mathrm{O}_{5}$ overnight. Yield $=0.736 \mathrm{~g}, 67.6 \%$. m. p. $=286-288{ }^{\circ} \mathrm{C} . \quad \lambda_{\max }(\mathrm{nm})(\mathrm{DMF}): 326$. IR $\left(v_{\max } \mathrm{cm}^{-1}(\mathrm{KBr}): 1619\left({ }_{\text {asym }} \mathrm{CO}_{2}^{-}\right), 1602(\mathrm{C}=\mathrm{N}-\mathrm{N}=\mathrm{C}), 1509\left(-\mathrm{NCO}^{-}\right), 1382\left({ }_{\mathrm{sym}} \mathrm{CO}_{2}^{-}\right)\right.$, $927(\mathrm{~N}-\mathrm{N}), 540$ (Sn-O), $483(\mathrm{Sn}-\mathrm{N}) .{ }^{1} \mathrm{H}$ NMR (300 MHz, DMSO- $\left.d_{6}\right): \delta 8.70,8.72(\mathrm{~d}, 2 \mathrm{H}$, 2,4-pyridine-H), $\delta 7.92,7.94$ (d, 2H, 3,5-pyridine-H), $\delta 2.30\left(\mathrm{~s}, 3 \mathrm{H},\left(\mathrm{H}_{3} \mathrm{C}\right) \mathrm{C}=\mathrm{N}\right), \delta 0.69(\mathrm{~s}$, $6 \mathrm{H}, \mathrm{Sn}-\mathrm{CH}_{3}$ ). Calc. for $\mathrm{C}_{9} \mathrm{H}_{7} \mathrm{~N}_{3} \mathrm{O}_{3} \mathrm{Me}_{2} \mathrm{Sn}$ : C, 37.39; H, 3.68; N, 11.90\%. Found: C, 37.40; $\mathrm{H}, 3.67$; N, $11.89 \%$.

\subsection{2. $\left[n-B u_{2} \mathrm{Sn}\left(\mathrm{C}_{9} \mathrm{H}_{7} \mathrm{~N}_{3} \mathrm{O}_{3}\right) \cdot \mathrm{H}_{2} \mathrm{O}\right]$ (3)}

Complex (3) was synthesized similarly to complex (2), using di-n-butyltin(IV) dichloride $(0.608 \mathrm{~g}, 0.002 \mathrm{~mole})$ instead of dimethyltin(IV) dichloride. Single crystals suitable for Xray diffraction studies were obtained by slow evaporation of methanol solution at room temperature. Yield $=0.882 \mathrm{~g}, 70.1 \%$. m. p. $=130-132{ }^{\circ} \mathrm{C} . \lambda_{\max }(\mathrm{nm})(\mathrm{DMF}): 326 . \mathrm{IR}$ $\left(v_{\max } \mathrm{cm}^{-1}(\mathrm{KBr}): 1618\left({ }_{\text {asym }} \mathrm{CO}_{2}{ }^{-}\right), 1603(\mathrm{C}=\mathrm{N}-\mathrm{N}=\mathrm{C}), 1508\left(\mathrm{NCO}^{-}\right), 1385\left({ }_{\text {sym }} \mathrm{CO}_{2}{ }^{-}\right), 925\right.$ $(\mathrm{N}-\mathrm{N}), 537$ (Sn-O), 485 (Sn-N). ${ }^{1} \mathrm{H}$ NMR (300 MHz, DMSO- $\left.d_{6}\right): \delta 8.71,8.73$ (d, 2H, 2,4pyridine-H), $\delta 7.90,7.91$ (d, 2H, 3,5-pyridine-H), $\delta 5.50$ (s, 2H, $\left.\mathrm{H}_{2} \mathrm{O}-\mathrm{Sn}\right), \delta 2.34$ (s, 3H, $\left.\left(\mathrm{H}_{3} \mathrm{C}\right) \mathrm{C}=\mathrm{N}\right), \delta$ 0.75-1.42 (m, $\left.18 \mathrm{H}, \mathrm{Sn}-\mathrm{Bu}\right)$. Calc. for $\mathrm{C}_{9} \mathrm{H}_{7} \mathrm{~N}_{3} \mathrm{O}_{3} \mathrm{Bu}_{2} \mathrm{Sn} . \mathrm{H}_{2} \mathrm{O}: \mathrm{C}, 44.84 ; \mathrm{H}$, $5.75 ; \mathrm{N}, 9.23 \%$. Found: C, 44.83; H, 5.74; N, 9.23\%.

\subsection{3. $\left[\mathrm{Ph}_{2} \mathrm{Sn}\left(\mathrm{C}_{9} \mathrm{H}_{7} \mathrm{~N}_{3} \mathrm{O}_{3}\right) \cdot \mathrm{H}_{2} \mathrm{O}\right]$ (4)}

Complex (4) was prepared similarly to complex (2), using diphenyltin(IV) dichloride $(0.688 \mathrm{~g}, 0.002 \mathrm{~mole})$ instead of dimethyltin(IV) dichloride. Yield $=0.878 \mathrm{~g}, 65.6 \%$. M. p. $=230-232{ }^{\circ} \mathrm{C} . \lambda_{\max }(\mathrm{nm})(\mathrm{DMF}): 329 . \mathrm{IR}\left(v_{\max } \mathrm{cm}^{-1}(\mathrm{KBr}): 1627\left({ }_{\text {asym }} \mathrm{CO}_{2}{ }^{-}\right), 1591(\mathrm{C}=\mathrm{N}-\right.$ $\mathrm{N}=\mathrm{C}), 1501\left(-\mathrm{NCO}^{-}\right), 1384\left({ }_{\text {sym }} \mathrm{CO}_{2}^{-}\right), 929(\mathrm{~N}-\mathrm{N}), 542(\mathrm{Sn}-\mathrm{O}), 492(\mathrm{Sn}-\mathrm{N}) .{ }^{1} \mathrm{H}$ NMR $(300$ MHz, DMSO- $\left.d_{6}\right): \delta 8.71,8.73(\mathrm{~d}, 2 \mathrm{H}, 2$,4-pyridine-H), $\delta$ 7.94, 7.96 (d, 2H, 3,5-pyridine$\mathrm{H}), \delta 5.55\left(\mathrm{~s}, 2 \mathrm{H}, \mathrm{H}_{2} \mathrm{O}-\mathrm{Sn}\right), \delta 2.23\left(\mathrm{~s}, 3 \mathrm{H},\left(\mathrm{H}_{3} \mathrm{C}\right) \mathrm{C}=\mathrm{N}\right), \delta$ 7.22-7.63 (m, 10H, Sn-Ph). Calc. For $\mathrm{C}_{9} \mathrm{H}_{7} \mathrm{~N}_{3} \mathrm{O}_{3} \mathrm{Ph}_{2} \mathrm{Sn}_{\mathrm{H}} \mathrm{H}$ O: C, 50.91; H, 3.84; N, 8.48\%. Found: C, 50.90; H, 3.85; N, $8.49 \%$.

\subsection{4. $\left[\mathrm{MeSnCl}\left(\mathrm{C}_{9} \mathrm{H}_{7} \mathrm{~N}_{3} \mathrm{O}_{3}\right) \cdot \mathrm{H}_{2} \mathrm{O}\right]$ (5)}

The procedure for the preparation of (5) was similar to the preparation of (2), with methyltin(IV) trichloride $(0.481 \mathrm{~g}, 0.002$ mole) used instead of dimethyltin(IV) dichloride and the refluxing time for this preparation was 2-3 hours. Yield $=0.714 \mathrm{~g}, 63.1 \%$. m. p. $=$ 244-246 ${ }^{\circ} \mathrm{C} . \lambda_{\max }(\mathrm{nm})(\mathrm{DMF}): 322 . \mathrm{IR}\left(v_{\max } \mathrm{cm}^{-1}(\mathrm{KBr}): 1620\left(\right.\right.$ asym $\left.\mathrm{CO}_{2}{ }^{-}\right), 1600(\mathrm{C}=\mathrm{N}-$ $\mathrm{N}=\mathrm{C}), 1508\left(-\mathrm{NCO}^{-}\right), 1382\left({ }_{\mathrm{sym}} \mathrm{CO}_{2}^{-}\right), 920(\mathrm{~N}-\mathrm{N}), 546(\mathrm{Sn}-\mathrm{O}), 493(\mathrm{Sn}-\mathrm{N}) .{ }^{1} \mathrm{H}$ NMR $(300$ MHz, DMSO- $\left.d_{6}\right): \delta 8.80,8.82(\mathrm{~d}, 2 \mathrm{H}, 2$,4-pyridine-H), $\delta 8.04,8.05$ (d, 2H, 3,5-pyridine$\mathrm{H}), \delta 5.30\left(\mathrm{~s}, 2 \mathrm{H}, \mathrm{H}_{2} \mathrm{O}-\mathrm{Sn}\right), \delta 2.40\left(\mathrm{~s}, 3 \mathrm{H},\left(\mathrm{H}_{3} \mathrm{C}\right) \mathrm{C}=\mathrm{N}\right), \delta 1.20\left(\mathrm{~s}, 3 \mathrm{H}, \mathrm{Sn}-\mathrm{CH}_{3}\right)$. Calc. For $\mathrm{C}_{9} \mathrm{H}_{7} \mathrm{~N}_{3} \mathrm{O}_{3} \mathrm{MeSnCl}_{.} \mathrm{H}_{2} \mathrm{O}: \mathrm{C}, 30.58 ; \mathrm{H}, 3.06 ; \mathrm{N}, 10.70 \%$. Found: C, 30.60; H, 3.05; N, $10.71 \%$. 


\subsection{5. $\left[\mathrm{PhSnCl}\left(\mathrm{C}_{9} \mathrm{H}_{7} \mathrm{~N}_{3} \mathrm{O}_{3}\right) \cdot \mathrm{H}_{2} \mathrm{O}\right](6)$}

The procedure for the preparation of (6) was similar to the preparation of (5), with phenyltin(IV) trichloride $(0.604 \mathrm{~g}, 0.002$ mole) used instead of methyltin(IV) trichloride. Yield $=0.767 \mathrm{~g}, 61.2 \%$. m. p. $=268-270{ }^{\circ} \mathrm{C} . \lambda_{\max }(\mathrm{nm})(\mathrm{DMF}): 325 . \mathrm{IR}\left(v_{\max } \mathrm{cm}^{-1}(\mathrm{KBr})\right.$ : $1621\left(_{\text {asym }} \mathrm{CO}_{2}^{-}\right), 1599(\mathrm{C}=\mathrm{N}-\mathrm{N}=\mathrm{C}), 1506\left(-\mathrm{NCO}^{-}\right), 1377\left({ }_{\text {sym }} \mathrm{CO}_{2}^{-}\right), 916(\mathrm{~N}-\mathrm{N}), 551(\mathrm{Sn}-$ O), 498 (Sn-N). ). ${ }^{1} \mathrm{H}$ NMR (300 MHz, DMSO- $\left.d_{6}\right): \delta 8.89,8.91$ (d, 2H, 2,4-pyridine-H), $\delta$ 7.99, 8.01 (d, 2H, 3,5-pyridine-H), $\delta 5.40$ (s, 2H, $\left.\mathrm{H}_{2} \mathrm{O}-\mathrm{Sn}\right), \delta 2.31\left(\mathrm{~s}, 3 \mathrm{H},\left(\mathrm{H}_{3} \mathrm{C}\right) \mathrm{C}=\mathrm{N}\right), \delta$ 7.29-7.78 (m, 5H, Sn-Ph). Calc. for $\mathrm{C}_{9} \mathrm{H}_{7} \mathrm{~N}_{3} \mathrm{O}_{3} \mathrm{PhSnCl} . \mathrm{H}_{2} \mathrm{O}$ : C, 39.65; H, 3.08; N, 9.24\%. Found: C, 39.62; H, 3.07; N, 9.25\%.

\subsubsection{Antibacterial activity}

The antibacterial activities of the ligand (1) and its organotin(IV) complexes (2-6) were studied by modified plate diffusion method [18] against Gram-positive and Gram-negative bacteria. Gram-positive bacteria species chosen in this assay were Staphylococcus aureus and Bacillus subtilis, whereas for Gram- negative bacteria, Escherichia coli was selected. Briefly, each species of the bacterial culture with optical density (OD) at 0.5-0.6 grown in nutrient media was swabbed thoroughly onto respective nutrient agar plates. Sterile paper disks impregnated with $0.2 \mu \mathrm{M}$ filtered sterilized hydrazone ligand or its individual complexes were aseptically transferred on the surface of inoculated nutrient agar surface in a maximum limit of 4 disks with similar distant apart assigned per plate. In the disks preparation, the hydrazone ligand and its individual complex at concentration of $3 \mathrm{mg} / \mathrm{mL}$ and $5 \mathrm{mg} / \mathrm{mL}$, respectively, were dissolved in DMSO before impregnating the disk with a fixed volume of $100 \mu \mathrm{L}$ sample per disk. Chloramphenicol at $3 \mathrm{mg} / \mathrm{mL}$ was employed as control. Disks were air dried under aseptic condition before being transferred to nutrient agar plates. Following overnight 24 -hour incubation at $37{ }^{\circ} \mathrm{C}$, zones of inhibition were measured in millimeters and the relative effectiveness of each compound was determined by comparing the diameter of inhibition zones. Each compound was tested in triplicate. The assay was carried out in a single batch to avoid batch-to-batch error.

\subsubsection{X-ray crystallography}

The measurements were performed at 273 (2) or 298 (2) K on Siemen SMART CCD diffraction using graphite-monochromated Mo-K $\alpha$ radiation $(\lambda=0.71073 \AA)$. Orientation matrix and unit cell parameters were obtained from the setting angles of 25-centered reflection. The structure was solved using direct methods and refined using the full-matrix least-square method on $\mathrm{F}_{\mathrm{obs}}{ }^{2}$ using the SHELXTL [19] software package. All non-H atoms were anisotropically refined. The hydrogen atoms were located in a difference Fourier map and then were fixed geometrically and treated as riding atom on the parent $\mathrm{C}$ atoms, with $\mathrm{C}$-H distances $=0.97 \AA$. 


\section{Acknowledgements}

The authors are very grateful to Universiti Malaysia Sarawak (UNIMAS) for financial support (Grant \# 01(S18)/639/2007(04). We would like to thank the School of Chemical Sciences and Food Technology, Universiti Kebangsaan Malaysia (UKM), for the CHN analyses and also X-ray single crystal structure determination. We also would like to thank the Ibnu Sina Institute, Universiti Teknologi Malaysia (UTM), for help in obtaining the ${ }^{1} \mathrm{H}$ NMR spectra.

\section{References}

1. C. Pettinari, F. Marchetti, R. Pettinari, D. Martini, A. Drozdov, and S. Troyanov, Inorg. Chim. Act. 325, 103 (2001). doi:10.1016/S0020-1693(01)00654-5

2. D. Sriram, P. Yogeeswari, and K. Madhu, Bioorg. \& Med. Chem. Lett. 15, 4502 (2005). doi:10.1016/j.bmcl.2005.07.011

3. H. D. Yin and S. W. Chen, J. Organomet. Chem. 691, 3103 (2006). doi:10.1016/j.jorganchem.2006.03.003

4. S. W. Ng, J. M. Hook, and M. Gielen, Appl. Organomet. Chem. 14, 1 (2000). doi:10.1002/(SICI)1099-0739(200001)14:1<1::AID-AOC930>3.0.CO;2-7

5. H. D. Yin, S. W. Chen, L. W. Li, and L. D. Wang, Inorg. Chim. Act. 360, 2215 (2007). doi:10.1016/j.ica.2006.10.038

6. M. A. Affan, Y. Z. Liew, B. A. Fasihuddin, B. S. Mustaffa, and M. Y. Bohari, ACGC Chem. Research. Comm. 20, 38 (2005).

7. M. A. Affan, Y. Z. Liew, B. A. Fasihuddin, M. Y. Bohari, and B. S. Mustaffa, Ind. J. Chem. 46 A, 1063 (2007).

8. W. G. Geary, Coord. Chem. Rev. 7, 81 (1971). doi:10.1016/S0010-8545(00)80009-0

9. A. Mukhopadhyay, G. Padmaja, P. Satyanarayan, and P. Samudranil, Inorg. Chem. Comm. 6, 381 (2003). doi:10.1016/S1387-7003(02)00795-5

10. Q. B. Song, X. L. Wu, Y. M. Liang, G. S. Huang, and Y. X. Ma, Polyhedron 15, 1303 (1996). doi:10.1016/0277-5387(95)00375-4

11. H. D. Yin, M. Hong, Q. B. Wang, Ind. J. Chem. 43 A, 2301 (2004).

12. H. D. Yin, M. Hong, Q.B. Wang, S. C. Xue, and D. Q. Wang, J. Organomet. Chem. 610, 1669 (2005). doi:10.1016/j.jorganchem.2004.12.037

13. S. G. Teoh, G. Y. Yeap, C. C. Loh, L. W. Foong, S. B. Teo, and H. K. Fun, Polyhedron 16, 2213 (1997). doi:10.1016/S0277-5387(96)00546-3

14. F. Eva, L. T. Elena, A. M. Ma, and T. S. Ma, Polyhedron 19, 441 (2000). doi:10.1016/S0277-5387(99)00383-6

15. A. A. Mohammad, A. H. Mirza, M. H. S. A. Hamid, and V. B. Paul, Polyhedron. 24, 383 (2005). doi:10.1016/j.poly.2004.11.023

16. M. Nath, R. Yadav, G. Eng, and P. Musingarimi, Appl. Organomet. Chem. 13, 29 (1999). doi:10.1002/(SICI) 1099-0739(199901)13:1<29::AID-AOC809>3.0.CO;2-D

17. C. Ma, Q. Jiang, and R. Zhang, Polyhedron. 23, 779 (2004). doi:10.1016/j.poly.2003.11.045

18. P. B. Sreeja, M. R. P. Kurup, A. Kishore, and C. Jasmin, Polyhedron 23, 575 (2004). doi:10.1016/j.poly.2003.11.005

19. G. M. Sheldrick. In: SHELXTL V5.1. Software Reference Manual. Bruker AXS. Madison, Inc., WI, USA (1997). 